\title{
Tako-tsubo kardiomyopatie indukovaná paragangliomem
}

\author{
(Paraganglioma-induced takotsubo cardiomyopathy)
}

\section{Petra Kadlečková, Tomáš Roubíček, Rostislav Polášek}

\author{
Kardiocentrum Krajské nemocnice Liberec, a.s., Liberec
}

INFORMACE O ČLÁNKU

Historie článku:

Vložen do systému: 28. 3. 2019

Přijat: 1. 4. 2019

Dostupný online: 3. 2. 2020

\section{Klíčová slova:}

Paragangliom

Paroxysmální hypertenze

Tako-tsubo kardiomyopatie

\section{SOUHRN}

Tako-tsubo kardiomyopatie (nazývaná též stresová kardiomyopatie či apikální balonový syndrom) je získané onemocnění myokardu charakterizované príznaky napodobujícími akutní koronární syndrom. Patofyziologický mechanismus tohoto onemocnění není stále zcela pochopen.

Obecně akceptovaným mechanismem je pravděpodobně katecholaminy indukované omráčení myokardu vyvolané stresem, nadměrnou fyzickou námahou nebo vzácně endokrinně aktivními tumory. Uvádíme kazuistiku pacienta, který byl přijímán na naše pracoviště pro podezření na akutní koronární syndrom. Následná vyšetření prokázala, že se jedná o stresovou kardiomyopatii, jejiž příčinou byl extraadrenálně lokalizovaný tumor - paragangliom. Jeho odstraněním došlo k úpravě jak klinických obtíži pacienta, tak laboratorních výsledkủ bez nutnosti užívání antihypertenzní i antidiabetické terapie.

(c) 2020, ČKS.
Keywords:

Paraganglioma

Paroxysmal hypertension

Takotsubo cardiomyopathy

\begin{abstract}
Takotsubo cardiomyopathy (also known as stress cardiomyopathy or apical balloon syndrome) is an acquired myocardial disease characterized by symptoms similar to acute coronary syndrome.

Pathophysiological mechanism of this disorder is still not well understood. Generally accepted mechanism is probably catecholamine-induced myocardial stunning provoked by stress, excessive physical exertion or rarely endocrine active tumors. We present a case report of a patient who was admitted to our clinic for suspected acute coronary syndrome. Subsequent examinations showed that it was a stress cardiomyopathy caused by extraadrenally localized tumor - paraganglioma.

By tumor extirpation all clinical symptoms and laboratory results were corrected without need of antihypertensive and antidiabetic therapy.
\end{abstract}

\section{Úvod}

Termín „tako-tsubo” byl poprvé popsán japonským lékařem dr. Satem v roce 1991 a vychází z názvu pro nádobu rybářů pro odchyt chobotnic. ${ }^{1} U$ pacientů s podezřením na akutní koronární syndrom je jeho prevalence asi 1-3\%, ${ }^{2}$ v prípadě žen až $10 \%$. ${ }^{3}$ Od roku 2006 do roku 2012 se frekvence tohoto onemocnění zvýšila dokonce dvacetkrát. ${ }^{4}$ Dle rozsáhlých výzkumů International Takotsubo Registry tvoři většinu pacientů (skoro 90 \%) ženy s průměrným věkem stanovení diagnózy 67 let. ${ }^{5}$ Prevalence mužů se nicméně zvyšuje.

Příčina není stále zcela jasná. Předpokládá se kombinace několika faktorů/mechanismů. Nejčastěji diskutovaným patofyziologickým mechanismem je omráčení myokardu na podkladě nadměrného působení katecholaminů, myokardiální toxicita, spasmus koronárních arterií a mikrovaskulární dysfunkce. ${ }^{6,7}$ Pro vznik je třeba tzv. triggerů, u žen častěji stres, u mužů pak fyzická námaha. Dalšími spouštěči bývají i endogenně aktivní tumory. ${ }^{8,9}$ Byly sledovány i rizikové faktory, díky jejichž prrítomnosti jsou pacienti ke vzniku tako-tsubo kardiomyopatie citlivější. Patří sem hormonální vlivy, genetické predispozice, psychiatrické a neurologické poruchy. 5,9,10

Paragangliomy jsou vzácné neuroendokrinní tumory vycházející z chromafinních buněk sympatických nebo parasympatických ganglií mimo dřeň nadledvin. Spolu s feochromocytomy je jejich incidence $0,8 / 100000$ osob. ${ }^{11} \mathrm{Ve}$ větší míře se nádory vyskytují sporadicky, mohou být ale i součástí genetických syndromů. ${ }^{12}$ Věk pacientů v době určení diagnózy se udává kolem 3.-5. decennia. ${ }^{13}$ Jejich endokrinní aktivita spočívá v produkci katecholaminů, které jsou zodpovědné za klinické projevy. Včasná diagnóza dokáže zabránit mnoha závažným komplikacím, a to nejen jeho ruptuře, útlaku okolních orgánů či metastatickému rozsevu, ale i projevům kardiovaskulárním, jako jsou zá- 


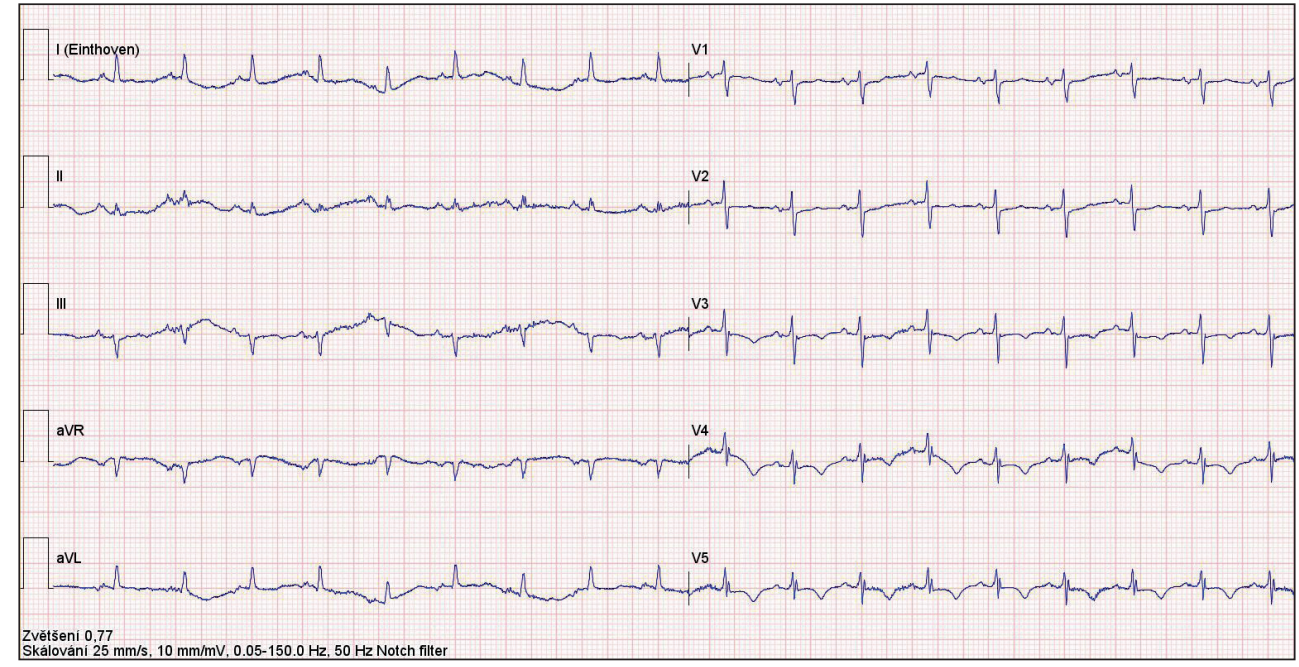

Obr. 1 - Vstupní EKG, na kterém jsou patrné negativní vlny $T$ ve svodech $V_{4}-V_{6}$.
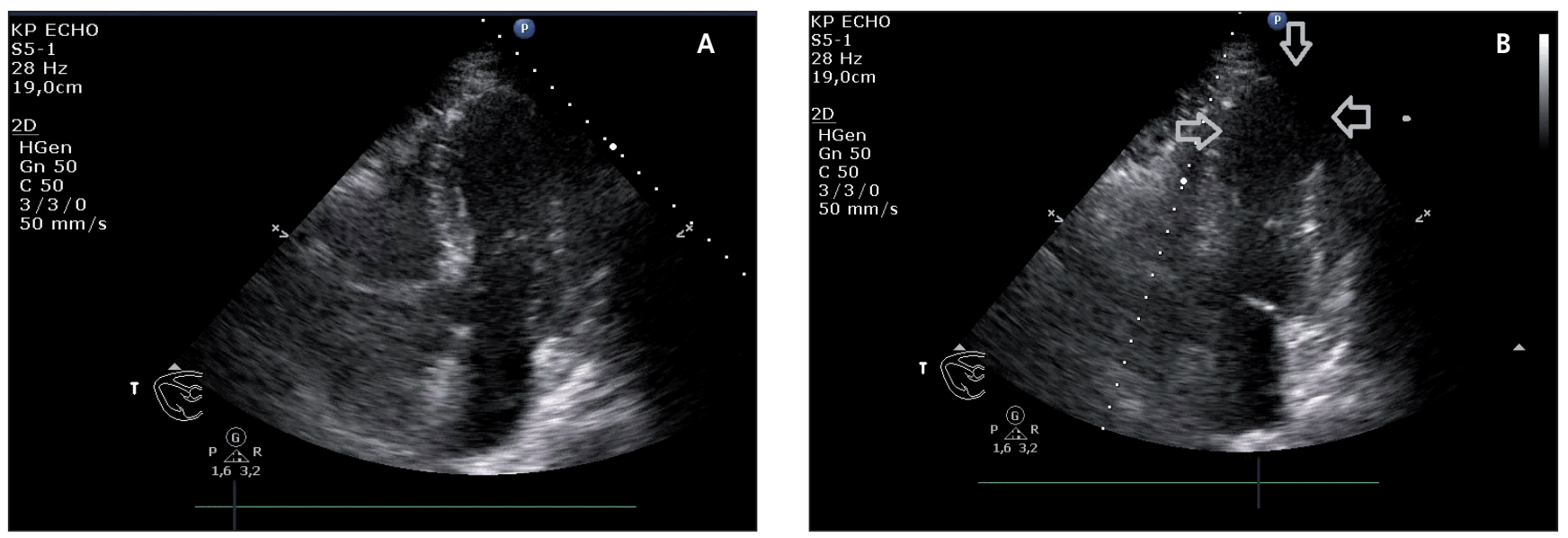

Obr. 2 - (A) TTE - projekce A4C v diastole, (B) TTE - v systole je patrné balonovité vyklenutí hrotu LK.

važné arytmie, cévní mozková příhoda, infarkt myokardu, akutní srdeční selhání, kardiogenní šok nebo v uvedené kazuistice katecholaminy indukované kardiomyopatii.

\section{Kazuistika}

Pětašedesátiletý kardiovaskulárně rizikový pacient, obézní diabetik 2. typu, léčený dietou a perorálními atidiabetiky, exkuřák s dyslipidemií, byl přijat pro bolesti na hrudi, dušnost a presynkopu.

Vstupně měl pacient známky srdečního selhání. Iniciální krevní tlak byl 95/55 mm Hg. Na EKG byly patrny inverze vln $T$ ve svodech $V_{3}-V_{6}$ (obr. 1). $V$ laboratoři byly vstupně zaznamenány vyšší hodnoty vysoce senzitivního troponinu T (550 ng/l při referenčním rozmezí < 14 ng/l).

Pacient byl přijat na koronární jednotku pro suspektní infarkt myokardu bez elevací úseku ST (NSTEMI) s projevy akutního srdečního selhání. Byla zahájena intravenózní diuretická terapie a onemocnění pacienta bylo zaléčeno jako akutní koronární syndrom. Již od př́ijmu byly dominantní kolísavé hodnoty krevního tlaku s cyklickými poklesy po přibližně 15 minutách. Vzestupy TK byly s maxi-

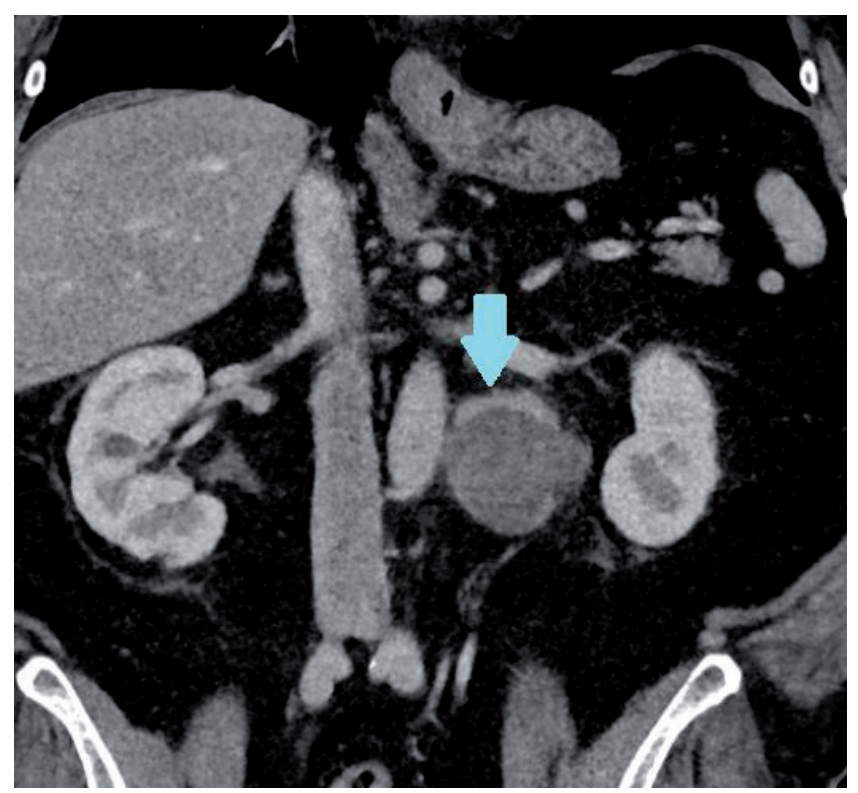

Obr. 3 - Paragangliom jako ovoidní expanze nasedající na subrenální aortu velikosti $67 \mathrm{~mm} \times 58 \mathrm{~mm} \times 45 \mathrm{~mm}$ 

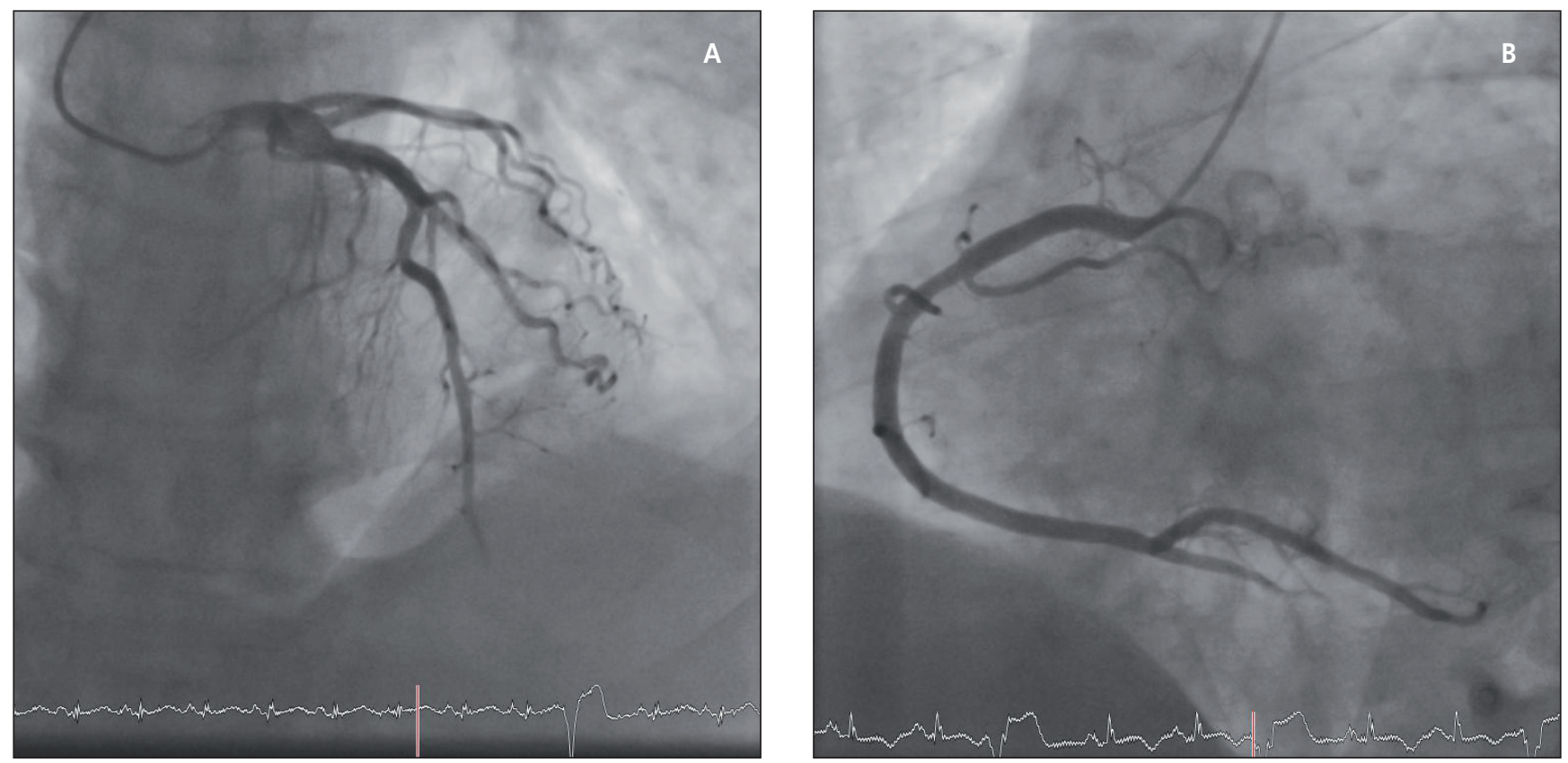

Obr. 4 - (A) Normální nález na ACS, (B) nevýznamné zúžení ACD. ACD - arteria coronaria dextra; ACS - arteria coronaria sinistra.

mem až 190/100 mm Hg a po podání malé dávky nitrátů následoval výrazný pokles s minimem až 70/30 mm Hg. Pacient byl nadále již bez bolestí na hrudi a koronarografie byla odložena. Echokardiografie prokázala lehkou systolickou dysfunkci levé komory s ejekční frakcí odhadem $45 \%$, těžkou hypokinezí hrotu a hyperkinezí bazálních segmentů (obr. 2A, 2B). Ve večerních hodinách týž den však došlo ke zvýraznění bolestí břicha. Bylo vysloveno podezření na disekci aorty nebo plicní embolii a provedena CT angiografie plic a břicha. Disekci ani plicní embolii CT vyšetření neprokázalo, překvapivým nálezem však byla solidní ovoidní expanze velikosti $67 \mathrm{~mm}$ vlevo paraaortálně subrenálně s podezřením na retroperitoneální tumor (obr. 3). Byla doplněna selektivní koronarografie (SKG) bez průkazu významné stenózy na věnčitých tepnách (obr. 4A, 4B).

Pro diagnózu tako-tsubo kardiomyopatie a suspektního endokrinně aktivního tumoru byl domluven překlad na specializované pracoviště (III. interní klinika 1. LF UK a VFN v Praze ). V dalším průběhu byl pacient již hemodynamicky stabilní, s regresí dušnosti a byl převeden na perorální terapii. Před překladem byly nasazeny $\alpha_{1}$-blokátory. Pacient dodatečně přiznal deset let silné pocení nezávisle na námaze a dlouhodobé bolesti zad léčené ambulantně jako vertebrogenní algický syndrom.

Pro podezření na funkční extraadrenální feochromocytom byly změřeny koncentrace metanefrinu, normetanefrinu a chromograninu, které vykazovaly zvýšené hodnoty. Doplněné PET/CT s podáním 18-FDG prokázalo suspektní paragangliom jako cystoidní formaci v levém retroperitoneu, místy se zvýšenou akumulací FDG. Metastázy prokázány nebyly.

Za měsíc byla provedena exstirpace podezřelého ložiska s nekomplikovaným průběhem. Dle biopsie se jednalo o středně diferencovaný paragangliom, GAPP score 6/10, dle WHO pT2, N0, MO. Po chirurgickém odnětí tumoru došlo k normalizaci hodnot krevního tlaku, glykemií, hodnot metanefrinů i jejich metabolitů a chromograninu. Došlo i k úpravě hodnoty glykemií a krevního tlaku ověřeného 24hodinovou monitorací. Byla proto vysazena nejen perorální antidiabetika, ale i antihypertenziva. Při provedené kontrolní echokardiografii došlo k reverzibilitě funkce i regionální kinetiky levé komory srdeční.

\section{Diskuse}

Diagnóza stresové kardiomyopatie je často zavádějící pro klinický obraz imitující akutní koronární syndrom.

Nejčastějšími klinickými projevy tako-tsubo kardiomyopatie jsou bolesti na hrudi, dušnost a pre/synkopa. K nejzávažnějším patři pak hypotenze, bradyarytmie či tachyarytmie včetně komorové tachykardie či fibrilace komor. Stav může vyústit až do kardiogenního šoku nebo je jeho prvním projevem náhlá smrt. K šoku může přispět i obstrukce výtokového traktu LK (LVOT) vyvolaná bazální hyperkinezí levé komory a může způsobit závažnou mitrální regurgitaci. Dalším projevem může být i cévní mozková príhoda na podkladě možného trombu lokalizovaného v hrotové části levé komory. 5,14

Laboratorně prokazujeme normální nebo mírně zvýšené hodnoty kreatinkinázy a nižší vrcholové koncentrace troponinu, které však nekorelují s rozsahem poruchy kinetiky. Naopak koncentrace natriuretických peptidů ve srovnání s akutním koronárním syndromem (AKS) jsou vysoké. ${ }^{5}$

Selektivní koronarografie (SKG) s ventrikulografií patři mezi zlaté standardy. Vyšetřením bývá vyloučena významná stenóza nebo okluze věnčitých tepen. Nicméně u 15,3 \% pacientů koronární postižení bývá. ${ }^{5}$

Echokardiografie prokazuje poruchy kinetiky, nejčastěji rozsáhlou akinezi až dyskinezi hrotu a hyperkinezi bazálních partií. Z rozsáhlých průzkumů mezinárodního registru tako-tsubo, konsorcia 26 center v Evropě a ve 
Spojených státech amerických, které se zabývá touto problematikou, je uváděna průměrná vstupní ejekční frakce levé komory $41 \% .^{5}$ Ač alternativní název „apikální balonový syndrom" odkazuje na nejčastější formu, dnes již víme, že se setkáváme i se zcela variabilními typy. Převažující apikální formy jsou prítomny u $82 \%$ pacientů dle International Takotsubo Registry. ${ }^{5}$ Méně časté formy, atypické, jsou pak midventrikulární typ s akinezí střední části komory s hyperkontraktilitou hrotu, reverzní typ neboli bazální či invertovaný s akinezí bazálních segmentů a hyperkontraktilitou hrotu a fokální s izolovanou dysfunkcí určitého segmentu. Vzácný je typ globální. 5,19

V naší kazuistice bylo vzhledem k značně rozmanitému klinickému obrazu zprvu obtížné vyslovit jasnou diagnózu. Abnormální EKG u pacientů se stresovou kardiomyopatií není žádnou výjimkou. Často bývají př́tomny denivelace úseku ST, spíše charakteru elevací, méně často deprese či inverze vln T jako v našem případě. Bývá prodloužen interval QT, můžou se vyskytovat i kmity Q. Normální EKG je spíše výjimkou. ${ }^{17}$

Od roku 2003 byla snaha vytvořit řadu kritérií usnadňující diagnostiku. Nejznámější byla doporučení Mayo Clinic, ${ }^{25,26}$ která byla užívána od roku 2004 a dále modifikována v roce 2008, jejichž praktické užívání se uplat'novalo nejvíc. Názory na jejich klinické využívání v praxi byly mezi lékaři rozpoluplné. ${ }^{16}$ Mezinárodním registrem tako-tsubo byla nedávno uvedena tzv. diagnostická kritéria InterTAK. ${ }^{10}$ Vyznačují se vysokou specificitou, nicméně i jejich nízké skóre neznamená $100 \%$ vyloučení a naopak maximální počet bodů nepotvrzuje diagnózu. Obsahuje sedm položek ohodnocených různým počtem bodů: ženské pohlaví, emocionální a fyzický stres, psychiatrická nebo neurologická porucha, prodloužený interval QTc a nepř́tomnost depresí úseku ST. Vylučujícím kritériem již zde není intrakraniální krvácení ani feochromocytom/ paragangliom. Naopak jsou označovány jako jeden ze spouštěčů. Skóre slouží především k rozhodnutí, zda provést SKG.

Jen část paragangliomů se projevuje klasickou triádou (palpitace, bolesti hlavy a pocení). Častější je dominantně paroxysmální arteriální hypertenze, v prípadě produkce dopaminu i hypotenze, dále dušnost, bledost, bolest z útlaků okolních orgánů, leukocytóza či hyperglykemie.

Diagnostika paragangliomů dnes spočívá nejprve v měření katecholaminů/adrenalinu, noradrenalinu a dopaminu a jejich metabolitů (metanefrinu a normetanerinu) v 24hodinovém sběru moči a v krvi. Častěji se stanovuje hodnota jejich metabolitů, protože hodnota adrenalinu a noradrenalinu může být falešně zvýšená $v$ důsledku prožitého stresu či fyzické aktivity. Doporučuje se upřednostňovat odběr plazmatických koncentrací, jelikož koncentrace metanefrinů $v$ moči může být falešně zvýšena v dưsledku užívání mnoha léků, hlavně antipsychotik. Falešná pozitivita je obecně udávána asi ve $20 \%$ př́padů. ${ }^{20}$

Po biochemickém testování je doporučováno doplnění CT vyšetření či magnetické rezonance (MR) k lokalizaci nádoru. V našem prrípadě byl nádor zjištěn náhodně, což není výjimkou. Udává se, že třetina až polovina těchto tumorů je diagnostikována náhodně, ${ }^{21}$ a 0,05-1 \% dokonce až při pitvě. K průkazu metastáz je nejvýhodnější použití 18F-fluorodeoxyglukózové pozitronové emisní tomografie (FDG-PET). ${ }^{22}$
Základem léčby paragangliomu je chirurgické odstranění tumoru, a to i v prípadě malignity vzhledem k lokálnímu riziku utlačování okolních struktur. Pro riziko adrenální krize během operace je dva týdny před výkonem indikována príprava $\alpha_{1}$-blokátory a poté beta-blokátory, což zabraňuje riziku hypertenzní krize při iritaci tumoru během výkonu. V př́ípadě nemožnosti chirurgické exstirpace tumoru je prováděna radioterapie.

Metastatické postižení je u parangliomu poměrně vzácné. Udává se především postižení lymfatických uzlin, kostí, jater a plic. O použití radiofrekvenční ablace, kryoablace a perkutánní injekce ethanolu bylo zatím publikováno jen omezené množství studií. ${ }^{23,24}$ Výsledky zatím svědčí pro pozitivní prínos těchto výkonů. Došlo tak ke snížení projevů přebytku katecholaminů, ústupu bolestí spojených s metastázami, zastavení lokálního šíření tumoru či progresi kostních, břišních a pánevních metastáz.

\section{Závěr}

Tako-tsubo kardiomyopatie je méně časté onemocnění myokardu, jehož přijetí jako reverzibilní formy bylo zpočátku kontroverzní. Díky neustálé úpravě diagnostických kritérií a progresivnímu vývoji oboru kardiologie jak v laboratorních, tak v diagnostických metodách a v jejich dostupnosti se počet pacientů s tímto onemocněním zněkolikanásobil. V případě kardiomyopatie indukované nádory s produkcí vazoaktivních katecholaminů je třeba často velmi důsledné diagnostiky a multioborové spolupráce. Paragangliomy zůstávají často náhodně zjištěnými tumory. Jejich klinické projevy však mohou vyvolat diagnostické rozpaky a při pozdním nálezu mít fatální následky.

Prohlášení autorů o možném střetu zájmů

Žádný střet zájmů.

\section{Literatura}

1. Sato $H$, Tateishi $H$, Uchida $T$. Takotsubo-type cardiomyopathy due to multivessel spasm, In: Kodama KK, Haze K, Hon M, eds. Clinical Aspect of Myocardial Injury: From Ischemia to Heart Failure ( in Japanese). Tokyo: Kagakuhyouronsya Co, 1990:5664.

2. Prasad A, Dangas G, Srinivasan M, et al. Incidence and angiographic characteristics of patients with apical ballooning syndrome (takotsubo/stress cardiomyopathy) in the HORIZONSAMI trial: an analysis from a multicenter, international study of ST-elevation. myocardial infarction. Catheter Cardiovasc Interv 2014;83:343-348.

3. Akashi YJ, Nef HM, Lyon AR. Epidemiology and pathophysiology of Takotsubo syndrome. Nat Rev Cardiol 2015:12:387-397.

4. Minhas AS, Hughey AB, Kolias TJ. Nationwide Trends in Reported Incidence of Takotsubo Cardiomyopathy from 2006 to 2012. Am J Cardiol 2015;116:1128-1131.

5. Templin C, Ghadri JR, Diekmann J, et al. Clinical Features and Outcomes of Takotsubo (Stress) Cardiomyopathy. N Engl J Med 2015;373:929-938.

6. Ferreira VM, Marcelino M, Piechnik SK, et al. Pheochromocytoma is Characterized by Catecholamine-Mediated myocarditis, Focal and Diffuse Myocardial Fibrosis, and Myocardial Dysfunction. J Am Coll Cardiol 2016;67:23642374. 
7. Wittstein IS, Thiemann DR, Lima JA, et al. Neurohumoral features of myocardial stunning due to sudden emotional stress. N Engl J Med 2005;352:539-548.

8. Schneider B, Athanasiadis A, Stöllberger C, et al. Gender differences in the manifestation of tako-tsubo cardiomyopathy. Int J Cardiol 2013;166:584-588.

9. Ghadri JR, Wittstein IS, Prasad A, et al. International Expert Consensus Document on Takotsubo Syndrome (Part I): Clinical Characteristics, Diagnostic Criteria, and Pathophysiology. Eur Heart J 2018;39:2032-2046.

10. Pison L, De Vusser $P$, Mullens W. Apical ballooning in relatives. Heart 2004;90:e67.

11. Beard CM, Sheps SG, Kurlanf LT, et al. Occurrence of pheochromocytoma in Rochester, Minnesota, 1950 through 1979. Mayo Clin Proc 1983;58:802-804.

12. Welander J, Söderkvist P, Gimm O. Genetics and clinical characteristics of hereditary pheochromocytomas and paragangliomas. Endocr Relat Cancer 2011;18:253-276.

13. Erickson D, Kudva YC, Ebersold MJ, et al. Benign Paragangliomas: Clinical presentation and treatment outcomes in 236 patients. J Clin Endocrinol Metab 2001;86:5210-5216.

14. Zalewska AM, Gajewska HB, Kazberuk AT, et al. Takotsubo cardiomyopathy: serious early complications and two-year mortality - a 101 case study. Neth Heart J 2016;24:511-519.

15. Gagnon N, Mansour S, Bitton Y, et al. Takotsubo-like cardiomyopathy in a large cohort of patients with pheochromocytoma and paraganglioma. Endocr Pract 2017:23:1178-1192.

16. Scantlebury DC, Prasad A. Diagnosis of Takotsubo cardiomyopathy. Circ J 2014:78:2129-2139.

17. Frangiegh AH, Obeid S, Ghadri JR. ECG Criteria to Differentiate Between Takotsubo (Stress) Cardiomyopathy and Myocardial Infarction. J Am Heart Assoc 2016;5:e003418.
18. Al-Harthy M, Al-Harthy S, Al-Otieschan A, et al. Comparison of pheochromocytomas and abdominal and pelvic paragangliomas with head and neck paragangliomas. Endocr Pract 2009;15:194-202.

19. Ghadri JR, Cammann VL, Napp LC, et al. International Takotsubo Registry, Differences in the Clinical Profile and Outcomes of Typical and Atypical Takotsubo Syndrome: Data From the International Takotsubo Registry. JAMA Cardiol 2016;1:335-340

20. Yu R, Wei M. False positive test results for pheochromocytoma from 2000 to 2008. Exp Clin Endocrinol Diabetes 2010;118:577585.

21. Wachtel H, Cerullo I, Bartlett EK, et al. Clinicopathologic characteristics of incidentally identified pheochromocytoma, Ann Surg Oncol 2014;22:132-138.

22. Nockel P, El Lakis M, Gaitanidis A, et al. Preoperative 18F-FDG $\mathrm{PET} / \mathrm{CT}$ in Pheochromocytomas and Paragangliomas Allows for Precision Surgery. Ann Surg 2019;269:741-747.

23. Kohlenberg J, Welch B, Hamidi O, et al. Efficacy and Safety of Ablative Therapy in the Treatment of Patients with Metastatic Pheochromocytoma and Paraganglioma Cancers 2019;11:E195.

24. McBride JF, Atwel TD, Charboneau WJ, et al. Minimally invasive treatment of metastatic pheochromocytoma and paraganglioma: efficacy and safety of radiofrequency ablation and cryoablation therapy. J Vasc Interv Radiol 2011;22:12631270

25. Kawai S, Kitabatake A, Tomoike H, et al. Guidelines for diagnosis of takotsubo (ampulla) cardiomyopathy. Circulation J 2007:71:990-992.

26. Bybee KA, Prasad A. Stress-Related Cardiomyopathy Syndromes. Circulation 2008;118:397-409. 